\title{
CAN WE BE WITH BEE ON MARS? EVALUATING THE IMPACT OF A ROCKET FLIGHT ON THE CONDITION OF HONEYBEES (APIS MELLIFERA)
}

\author{
Dagmara Stasiowska \\ AGH University of Science and Technology \\ al. Mickiewicza 30, 30-059 Cracow, Poland \\ stasiowska@agh.edu.pl•ORCID: 0000-0002-9047-9814
}

\begin{abstract}
In paper the issue of a rocket flight impact and overall survivability of such flight by Apis mellifera (western honeybees) specimens is raised. Author claims that it is the key for using them on Mars for pollination in future, as this species is considered as one of the best pollinators, and should be examined before sending first human missions to the Red Planet. Rocket payload 'BeeO!Logical' was designed in order to conduct the research, the first of its kind worldwide. Its assumptions are presented along with overall descriptions of the experiments in two sounding rockets. Analysed data included survivability, carbon dioxide concentration values (respiration levels), temperature and humidity. It has been shown that $A$. mellifera specimens are able to survive the rocket flight. Project development possibilities are described, including widening the scope of the research with bumblebees (Bombus) and implementation of biocybernetic model of bee colony.
\end{abstract}

Keywords: honeybees, rocket, payload, Mars terraformation.

\section{INTRODUCTION}

Along with cargo missions to Mars construction of first greenhouses there will begin, to satisfy nutritional needs of all future Mars citizens. This moment is now closer than ever, as Elon Musk claims that SpaceX in 2022 will send first such mission, and then, in 2024, both cargo and a human crew [1]. At the same time Food and Agriculture Organization of the United Nations claims that close to $75 \%$ of the world's crops, producing fruits and seeds for human consumption, depend, at least to some extent, on pollinators [2]. There is a need then to examine the impact of transportation of pollinators by rockets, to ensure that they are able to operate correctly even after such kind of stress. The best well known pollinator by now are bees (Anthophila) [3]. Studies on bumblebees (Bombus impatiens) [4] and honeybees [5] were conducted in past, but none of them considered the impact of a rocket flight by itself on their condition. Author claims that surviving the flight in a good condition is the key for further proper pollination and should be examined before sending first representatives of the species to the Mars. Moreover first generation of $A$. mellifera specimens, which will be transported to the Red Planet is particularly important because they will give rise to all future generations, so their condition must be irreproachable. The main goal of this research is to evaluate the impact of a rocket flight on honeybees (A. mellifera) survivability. Additionally overall post-flight condition and respiration levels are checked. 


\section{MATERIAL AND METHODS}

\section{Assumptions}

Rocket payload 'BeeO!Logical' was designed to take part in SDL Payload Challenge 2019 during Intercollegiate Rocket Engineering Competition (IREC) in New Mexico, USA, the largest student rocket competition worldwide. Considering its requirements along with mechanical properties of the rocket and requirements for payload design in private companies (e.g. Blue Origin [6]), the following guidelines were established:

- The payload should perform a scientific experiment, with no vertebrates on board - competition requirement,

- It should have a minimum weight of $8.8 \mathrm{lbs}$ and a maximum of $10 \mathrm{lbs}$ - competition requirement,

- It must function as an independent subsystem of the rocket with no interference with the vehicle's stability and performance - competition requirement,

- It must not contain any form of toxic materials - competition requirement,

- It should have a CubeSat format, ideally $3 \mathrm{U}(10 \times 10 \times 30 \mathrm{~cm})$ - competition requirement, additionally such design allows using the same payload configuration during commercial launch [6],

- It must be hermetic - required due to usage of $\mathrm{CO}_{2}$ sensor, which measures the difference in carbon dioxide concentration in tested sample (TS) and control sample (CS),

- It must be possibly shockproof - to protect the interior, fragile electronics and the honeybees,

- Each box should contain sufficient amount of air that allows honeybees ( . mellifera) to live for at least 4 hours - predicted rocket mission duration time during competition,

- The payload subsystem should take all electronics systems necessary - competition requirement and generally necessary during commercial launch,

- Its design should focus on modular and lightweight structure so that it could be incorporated in stratospheric balloon gondola - assumption made for simplified widening scope of research on A. mellifera,

- Honeybees should come from possibly one colony with known genetic history - for data interpretation simplification and for the exclusion of genetic variables in order to minimize the influence of genes on experiment results. In Poland fulfilled by cooperation with Pasieka Szeligów apiary, which also conducts further research after successful missions,

- CS must be present for all experiments and be stored nearby the launchpad - for minimizing impact of external conditions on data and simplification of interpretation differences between both samples.

\section{Description}

Experiment was designed according to shown assumptions. Due to biological nature of experiment there was a need to divide studied objects in two groups - 'tested sample' (TS) and 'control sample' (CS). Such operation ensures reliability of experiment and disclaims errors related to, e.g., genetics of studied specimens.

Both samples' design was identical with exception to anti-shock case - TS, exposed to vibrations related to rocket launch, had it made of $2 \mathrm{~mm}$ thick stainless steel, while CS, which did not require extra stiffness, had it made of plywood. Both samples were present during each experiment. While TS was placed in the rocket, CS was stored nearby the launchpad, in order to keep conditions as similar as possible (with exception to rocket flight).

Samples size was determined basing on general rules for determining biological sample size [7], however equally important was quantity of bees that apiary was able to provide during an experiment and also possible to examine after tests. Basing on those two factors it was decided CS and TS will consist 4 sections with bees each. 


\section{Design}

The 'BeeO!Logical' payload consists of 2 identical copies of itself - TS and CS. Each of them is composed of 4 main mechanical parts - Electronic box (EB), biological boxes (BB), thermal insulation and anti-shock case (Pic.1), only one different part for TS and CS, as mentioned in chapter 2.2.

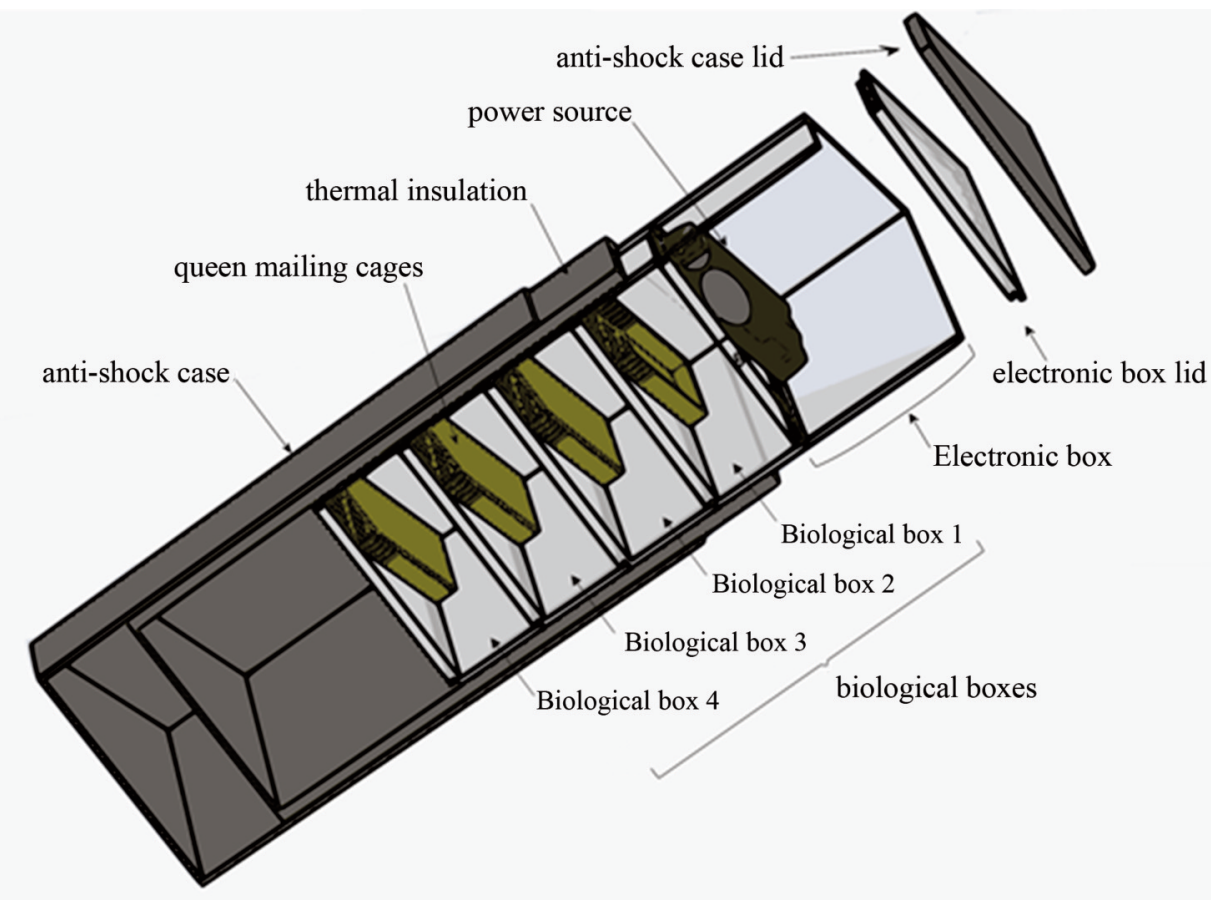

Figure 1. Payload's design conceptual diagram (based on own research).

External dimensions of 'BeeO!Logical' were forced by IREC requirements, as well as are typical ones required by private companies. The most external anti-shock case was made of $2 \mathrm{~mm}$ thick stainless steel to ensure required stiffness and vibrations resistance. Lid of this case was made of $6 \mathrm{~mm}$ stainless steel, what, with dedicated adapters, made it an interface for mounting payload in the rocket. Figure 2 presents predicted deformations of case, with assumption that maximum force impacting will be equal $6.5 \mathrm{G}$. Analysis was done with Ansys program by MSc Eng. Michał Pyza.

For thermal insulation Porogel Medium Spaceloft (PMS) was used, due to its relatively low thickness $(5 \mathrm{~mm})$ in comparison with similar materials, e.g. glasswool. Moreover its thermal conductivity is more than two times lower than for compared URSA GLASSWOOL $(0.015 \mathrm{~W} / \mathrm{mK}$ vs $0.035 \mathrm{~W} / \mathrm{mK})[8,9]$, what mainly is ensured by using of silica aerogel in PMS composition.

Electronic and biological boxes were made of polycarbonate, $2 \mathrm{~mm}$ thick. Material was chosen due to its good mechanical and thermal properties, low mass and easy processing, while being more durable than acrylic glass. Low mass of main part of payload was critical as it was supposed to be used also in stratospheric balloon mission, which requires as low mass of gondola as possible.

'BeeLogic', main on-board computer of payload, was custom-made printed circuit board, designed by Bartosz Zieliński. Module was responsible for data acquisition from several units and gathering them on flash memory. All was controlled by STM32 microcontroller and powered from 4 alkaline batteries, AA type. 

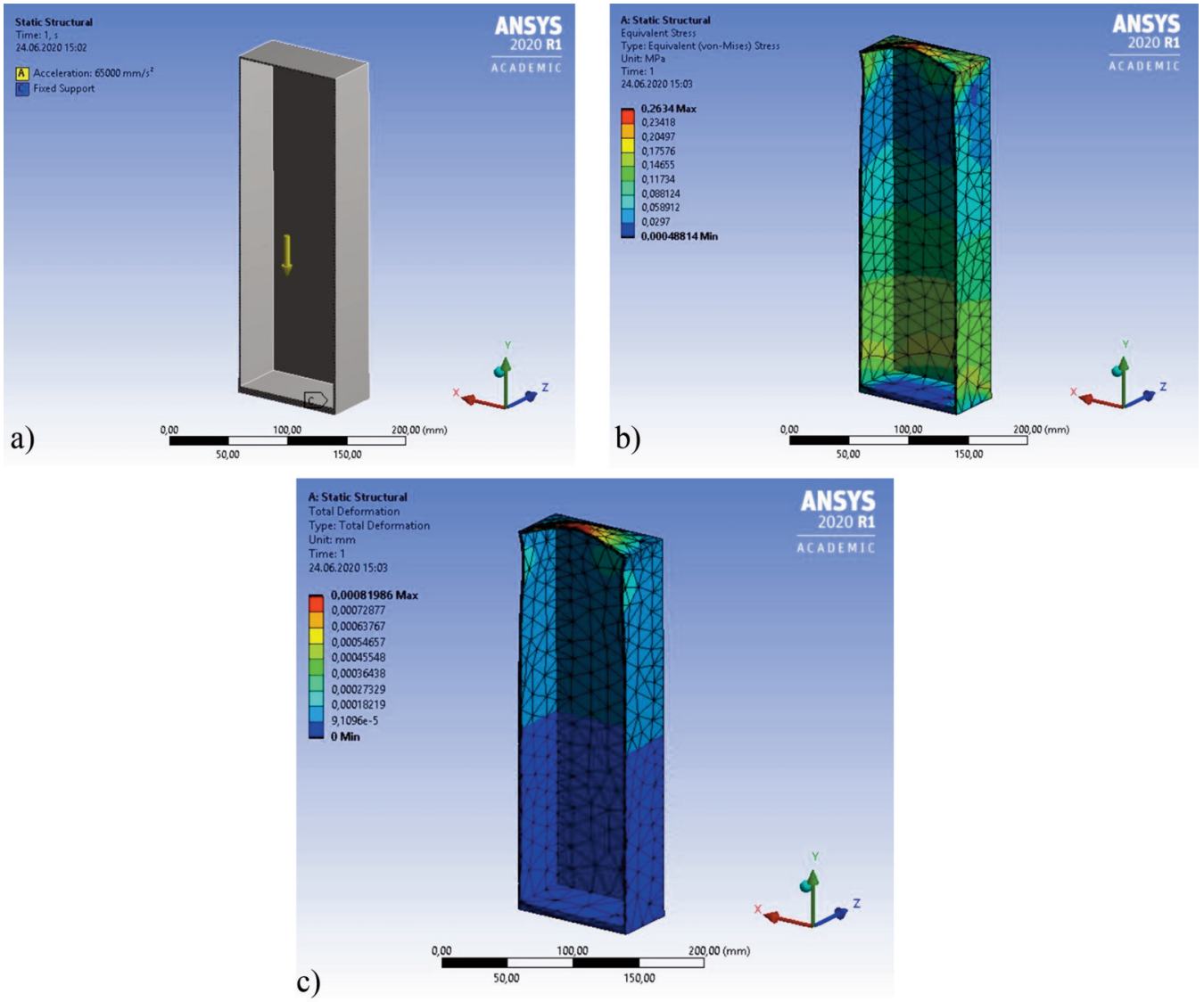

Figure 2. Prediction of the response of the anti-shock case structure under loading: (a) load given (6.5 G), (b) stress distribution analysis, (c) deformations prediction.

Models of sensors were chosen mainly basing on the previous experience. It was decided to collect data from several sensors. As the most important for experiment barometric pressure, humidity, temperature and $\mathrm{CO}_{2}$ sensors were chosen and basic data about them is given in Table 1 . There is specific temperature range which honeybees typically are maintaining in hive [10], variations from this values can affect specimens negatively. The same thing is about humidity [11]. Pressure measurement could help detect any leaks in payload, which would have negative impact on carbon dioxide measurement. $\mathrm{CO}_{2}$ sensor was used due to correlation between stress level and amount of exhaled $\mathrm{CO}_{2}$. Existence of such dependence was proven for different species of insects, including A. mellifera [12].

Table 1. Types of used sensors, their measurement ranges, accuracy and placing in the payload.

\begin{tabular}{|l|c|c|c|c|}
\hline Sensor type & Measured variable & Measurement range & Accuracy & Placement in the payload \\
\hline SCD30 & $\mathrm{CO}_{2}$ & $0-40000 \mathrm{ppm}$ & $\pm 30 \mathrm{ppm}$ & Biological box 1 \\
\hline SCD30 & Temperature & $-40-+70{ }^{\circ} \mathrm{C}$ & $\pm 0.4{ }^{\circ} \mathrm{C}$ & Biological box 1 \\
\hline SCD30 & Humidity & $0-100 \% \mathrm{RH}$ & $\pm 3 \% \mathrm{RH}$ & Biological box 1 \\
\hline MS5607 & Barometric pressure & $10-1200 \mathrm{mbar}$ & $\pm 1.5 \mathrm{mbar}$ & Electronic box \\
\hline
\end{tabular}

G-force values were measured by rockets' on-board computers. 
Specimens of $A$. mellifera were placed in a basic model of queen mailing cages, typically used for transportation. Such solution simplified both designing process and assembling of payload thanks to no need to relocate bees several times and give them to additional stress, which could affect experiment results negatively.

\section{EXPERIMENTS}

Experiments were conducted, using different platforms and configurations.

Table 2. List of conducted experiments with rockets' names, list of bees' functions that were tested and changes in configuration of 'BeeO!Logical' (based on own research).

\begin{tabular}{|l|c|c|c|c|c|c|}
\hline Platform & Place & Date & $\begin{array}{c}\text { Number } \\
\text { of BB in } \\
\text { sample }\end{array}$ & $\begin{array}{c}\text { Queens' } \\
\text { presence } \\
\text { [Y/N] }\end{array}$ & $\begin{array}{c}\text { Tested bees' } \\
\text { functions }\end{array}$ & Other comments \\
\hline $\begin{array}{l}\text { Rocket } \\
\text { 'Carbonara' }\end{array}$ & $\begin{array}{c}\text { Błędów } \\
\text { Desert, } \\
\text { Poland }\end{array}$ & 17.05 .2019 & 3 & $\mathrm{~N}$ & $\begin{array}{c}\text { Respiration } \\
\text { levels } \\
\text { Overall condition }\end{array}$ & $\begin{array}{c}\text { Different thermal } \\
\text { insulation (space } \\
\text { blanket) } \\
\text { No anti-shock case }\end{array}$ \\
\hline $\begin{array}{l}\text { Rocket } \\
\text { 'PROtotype' }\end{array}$ & $\begin{array}{c}\text { Spaceport } \\
\text { America, } \\
\text { New Mexico } \\
\text { (NM), USA }\end{array}$ & 21.06 .2019 & 4 & $\mathrm{~N}$ & $\begin{array}{c}\text { Respiration } \\
\text { levels } \\
\text { Overall condition }\end{array}$ & No launch \\
\hline $\begin{array}{c}\text { Rocket } \\
\text { 'PROtotype' }\end{array}$ & $\begin{array}{c}\text { Spaceport } \\
\text { America, } \\
\text { NM, USA }\end{array}$ & 22.06 .2019 & 4 & $\mathrm{~N}$ & $\begin{array}{c}\text { Respiration } \\
\text { levels } \\
\text { Overall condition }\end{array}$ & $\begin{array}{c}21^{\text {st }} \text { were used (2nd day } \\
\text { of being enclosing in } \\
\text { small box) } \\
\text { No launch }\end{array}$ \\
\hline $\begin{array}{l}\text { Rocket } \\
\text { 'PROtotype' }\end{array}$ & $\begin{array}{c}\text { Spaceport } \\
\text { America, } \\
\text { NM, USA }\end{array}$ & 23.06 .2019 & 4 & $\mathrm{~N}$ & $\begin{array}{c}\text { Respiration } \\
\text { levels } \\
\text { Overall condition }\end{array}$ & $\begin{array}{c}21^{\text {st }} \text { and } 22^{\text {nd }} \text { were } \\
\text { used } 3^{\text {rd }} \text { day of being } \\
\text { enclosing in small box) } \\
\text { Rocket failure }\end{array}$ \\
\hline
\end{tabular}

Except differences shown in Table 2, payload during each experiment used the same components, main computer ('BeeLogic'), sensors and procedures in order to minimize impact of such changes on results. Each time CS was operated exactly the same way as TS. It was also transported to the launchpad along with TS, only significant difference was not placing it in the rocket.

'PROtotype' rocket failure mentioned in Table 2 was caused by leak in the feed system, after 1 second of engine's nominal work. It caused dramatic direction change and achieving only 225 meters of apogee with initial acceleration about $6.5 \mathrm{G}$.

Study shows that absence of queen causes workers' higher stress levels [13]. This is a cause of considering queens' presence in queen mailing cages in Table 2.

The same specimens were used for all three launch attempts due to low availability of honeybees in US.

\section{RESULTS}

Experiment in 'Carbonara' rocket survived all specimens from TS. After simultaneous cages' opening of both samples, tested one was slower and less ready for immediate flight. Ultimately it took them around 7 minutes since first flight attempt to actual flight. 17 worker bees were in TS and 15 in CS. 
No body damages were noticed after flight. No useful data from $\mathrm{CO}_{2}$ sensor was collected as it crashed and gave unreliable measurements (out of range). Temperature and relative humidity values are shown below in Table 3 .

Table 3. Temperature and humidity ranges inside TS and CS during experiment in 'Carbonara' rocket - minimum, average, median and maximum values (based on own research).

\begin{tabular}{|l|c|c|c|c|}
\hline \multirow{2}{*}{ Value } & \multicolumn{2}{|c|}{ Temperature $\left[{ }^{\circ} \mathrm{C}\right]$} & \multicolumn{2}{c|}{ Humidity [\%] } \\
\cline { 2 - 5 } & TS & CS & TS & CS \\
\hline Minimum & 21.0 & 20.0 & 47.0 & 50.0 \\
\hline Average & 25.0 & 23.3 & 56.4 & 56.0 \\
\hline Median & 26.0 & 22.0 & 57.0 & 56.0 \\
\hline Maximum & 31.0 & 30.0 & 61.0 & 62.0 \\
\hline
\end{tabular}

During tests in 'PROtotype' rocket the same specimens were used for 3 days. Such decision was made due to serious issues with getting honeybees in US. Initially in CS was 16 specimens and 19 in TS. After last day of experiments $88 \%$ of CS and $75 \%$ of TS was still alive (Table 4)

Table 4. Comparison of total number of alive specimens of A. mellifera in sample for tests in "PROtotype" rocket (based on own research).

\begin{tabular}{|c|c|c|c|}
\hline \multirow{2}{*}{ Date } & \multirow{2}{*}{$\begin{array}{l}\text { Status (before }[\mathrm{B}] / \text { after } \\
{[\mathrm{A}] \text { the experiment) }}\end{array}$} & \multicolumn{2}{|c|}{ Number of specimens } \\
\hline & & TS & $\mathrm{CS}$ \\
\hline \multirow{2}{*}{ 21.06.2019 } & B & 19 & 16 \\
\hline & A & 14 & 13 \\
\hline \multicolumn{2}{|c|}{ Survivability [\%] } & 73.7 & 81.3 \\
\hline \multirow{2}{*}{ 22.06.2019 } & $\mathrm{B}$ & 14 & 13 \\
\hline & A & 13 & 11 \\
\hline \multicolumn{2}{|c|}{ Survivability [\%] } & 92.9 & 84.6 \\
\hline \multirow{2}{*}{ 23.06.2019 } & B & 11 & 13 \\
\hline & A & 6 & 13 \\
\hline \multicolumn{2}{|c|}{ Survivability [\%] } & 54.5 & 100 \\
\hline \multicolumn{2}{|c|}{ Average survivability [\%] } & 75.0 & 88.1 \\
\hline
\end{tabular}

The only significant survivability test was the last one, as it was the only one when rocket was launched. Rest of tests shows impact of enclosing specimens in 'BeeO!Logical' by itself. As can be seen in Table 4 their survivability in such case is similar and equals about $83 \%$. Average survivability is a combination of impact of enclosing bees in payload with impact of rocket launch. Ordinary duration of enclosing specimens inside payload was 7.5 hours.

Despite rocket failure mentioned in chapter 2.4, payload was found in good condition. Anti-shock case protected all inner parts of payload. Only breakage was dehermetization of one of biological boxes without a sensor inside. All queen mailing cages, as well as bees, were not harmed, biological box with the $\mathrm{CO}_{2}$ sensor was enclosed properly, no leaks were seen. Rocket was recovered only on the drogue parachute, as the main one had not enough time to open, what made the touchdown hard. Those specific conditions caused that acceleration and other forces were not only upward, but also some in circular pattern, what makes it even more interesting.

Specific data about temperature and humidity ranges inside the payload can be seen in Table 5 . Temperature was very similar for both samples - difference in medium value is noticeable from second decimal place, so it is not even included in Table 4. 
Table 5. Temperature and humidity ranges inside TS and CS during experiment in 'PROtotype' rocket, 23.06.2019 - minimum, medium, median and maximum values (based on own research).

\begin{tabular}{|l|c|c|c|c|}
\hline \multirow{2}{*}{ Value } & \multicolumn{2}{|c|}{ Temperature $\left[{ }^{\circ} \mathrm{C}\right]$} & \multicolumn{2}{c|}{ Humidity [\%] } \\
\cline { 2 - 5 } & TS & CS & TS & CS \\
\hline Minimum & 25.0 & 25.0 & 53.0 & 32.0 \\
\hline Average & 27.4 & 27.4 & 58.9 & 39.6 \\
\hline Median & 28.0 & 28.0 & 59.0 & 39.0 \\
\hline Maximum & 29.0 & 29.0 & 63.0 & 43.0 \\
\hline
\end{tabular}

Very inquiring measurement from $\mathrm{CO}_{2}$ sensors comes from 21.06.2019, first minutes of measurement (Figure 3, Figure 4).

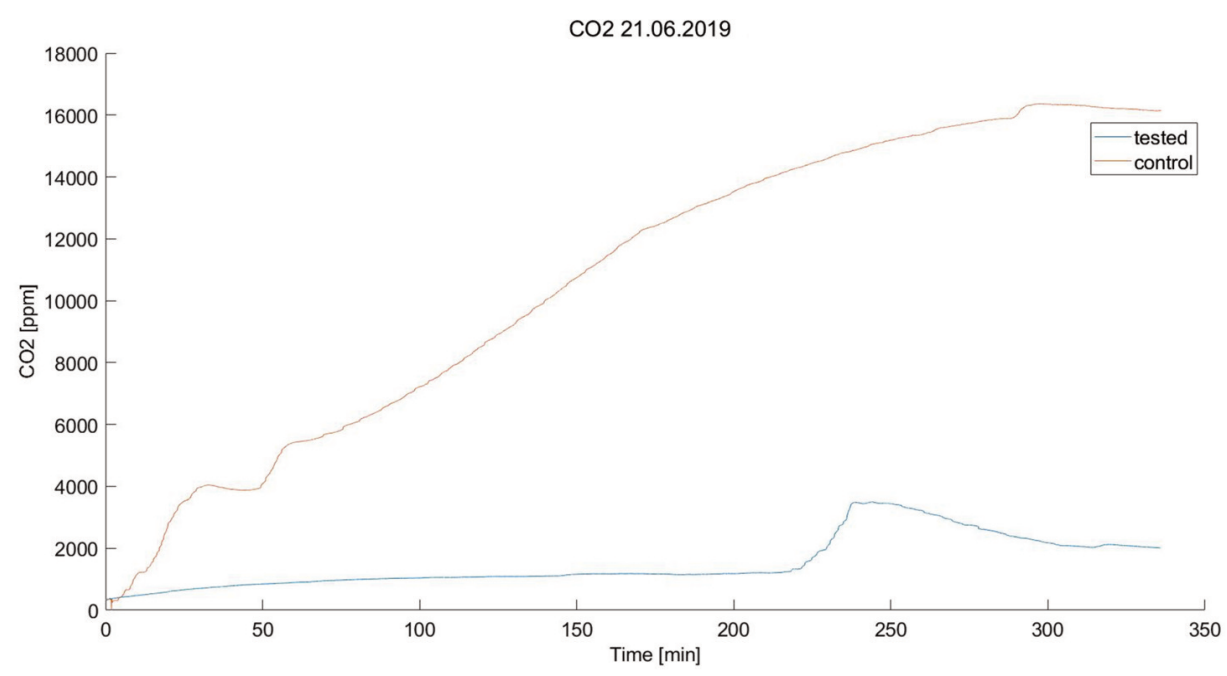

Figure 3. $\mathrm{CO}_{2}$ concentration value change in time for samples - 21.06.2019 (based on own research)

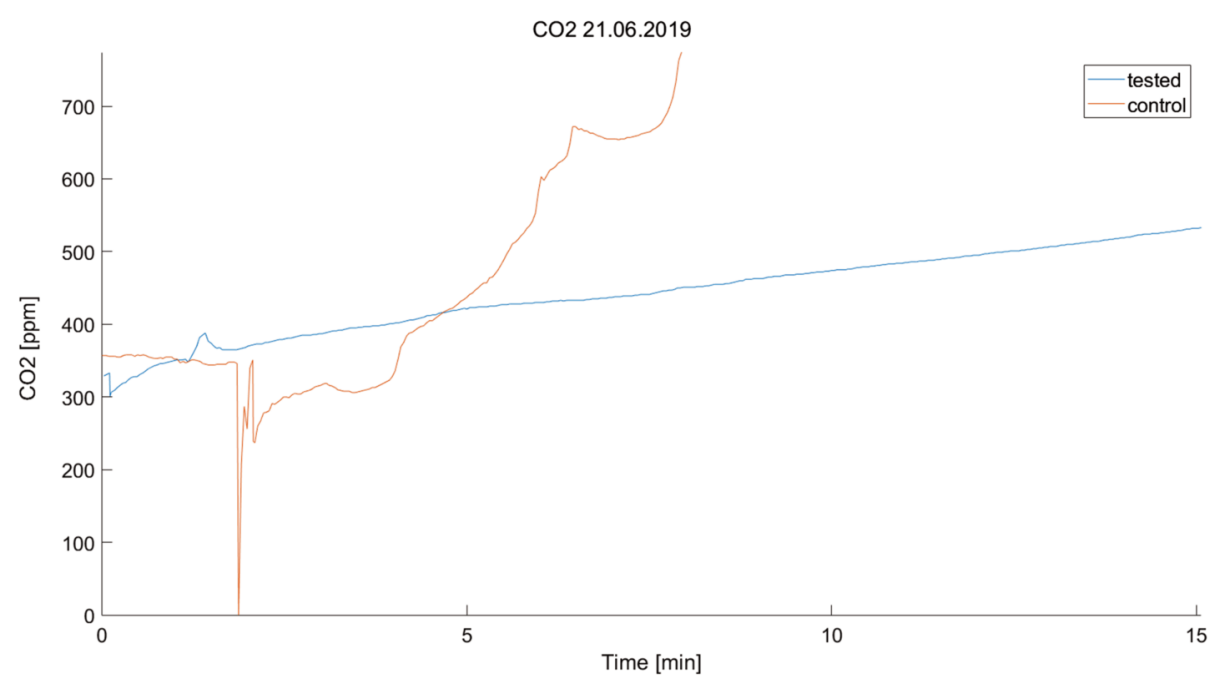

Figure 4. Initial values of $\mathrm{CO}_{2}$ concentration during experiment from 21.06.2019 for both samples (based on own research) 
Excluding sudden drop of the carbon dioxide concentration value in -2 minute of experiment (related to bug in processor timer), initial measurement in time ' 0 ' has very similar value for both samples and equals around $350 \mathrm{ppm}$. It confirms proper calibration of sensors, as measured value responds to the one measured every year on Mauna Loa and being the equivalent of $\mathrm{CO}_{2}$ concentration in atmosphere [14].

Interestingly $\mathrm{CO}_{2}$ concentration value rises significantly for control sample, not for tested one. Most probably it is caused by leak in payload's mechanical structure.

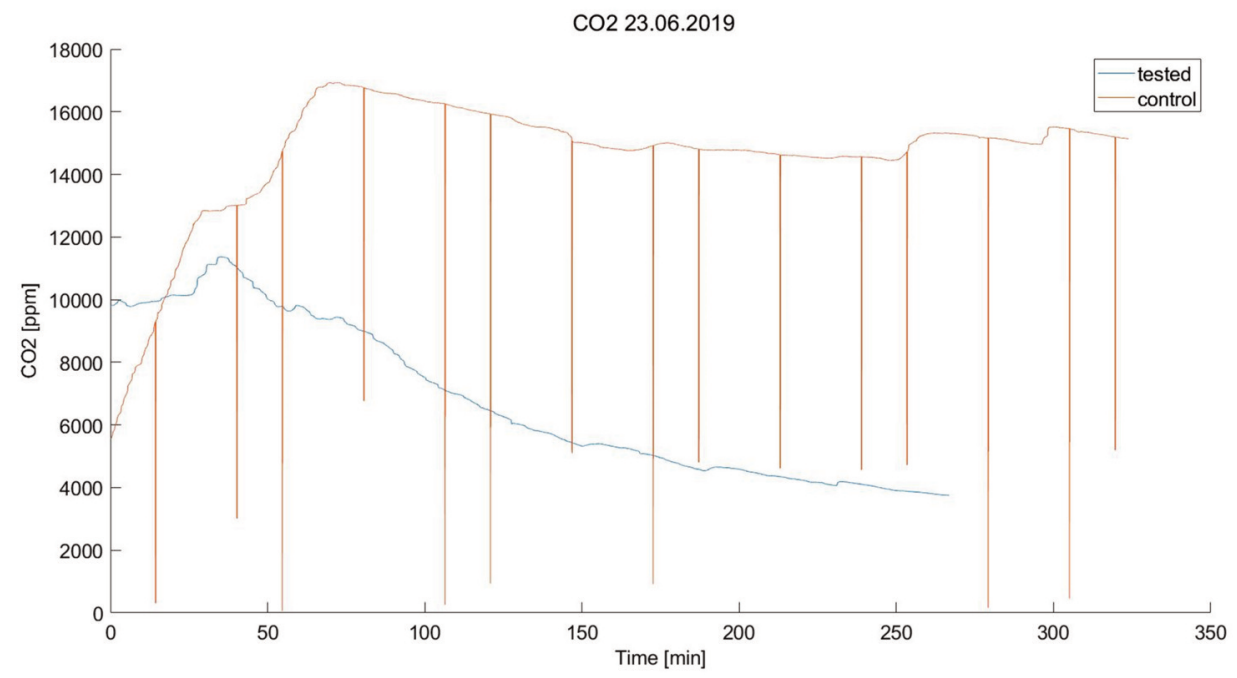

Figure 5. $\mathrm{CO}_{2}$ concentration value change in time for samples - 23.06.2019 (based on own research). Sudden, periodical drops of value in control sample are errors caused by processor and should not be taken into consideration.

Measurements from $23^{\text {rd }}$ of June are incomplete - electronics in TS stopped working about 15 minutes before rocket launch. Reason of such situation was not recognized. However it can be seen approximately stable value of $\mathrm{CO}_{2}$ concentration in CS, what is justified by stable number of alive specimens in sample. In case of TS value dropped more than two times from the initial one (Figure 5) - the situation is partially reflected in data about number of alive bees after experiment, as almost half of the sample died during test. Reason for the decrease bigger than expected was not identified.

\section{DISCUSSION}

As it can be seen both in Table 3 and Table 5 temperature and humidity measurements are very similar for both samples during experiments. It proves that they are prepared correctly and assumptions about their sameness are achieved.

Only one difference of unknown origin is the humidity measurement from 23.06.2019, done during competition in New Mexico, USA, shown in Table 5. Mean difference between TS and CS in humidity values is 20 percentage points. The exact reason is not known but author thinks that it may be caused by combining two factors - initial humidity difference and location of both samples. Initial difference was 14 percentage points. After enclosing samples natural effect is growth of those values, as the specimens breathe. It was the case for TS, as it was enclosed additionally in the rocket. CS was stored in the shadow, but without any extra coating (outermost part was the plywood anti-shock case). High temperature caused constant evaporation of humid. 
Even when all $A$. mellifera specimens survived, as in case of 'Carbonara' rocket test, easily visible was change in their behaviour and readiness for flight. Such situation was not caused by carbon dioxide poisoning because in such situation it would appear in both samples, not only in tested one. Acceleration during that specific launch was not measured due to electronics failure, but typical values for this rocket are around $3 \mathrm{G}$.

During 'PROtotype' rocket launch measured was $6.5 \mathrm{G}$ force, which more than half of sample survived. Although due to the flight was short and not standard one, further research are needed to check the repeatability of results and their compliance with results of the standard flight with no errors.

During experiment vibrations generated by both rockets were not measured. Despite that fact, both rockets, due to the same engine type usage and similar dimensions as well as predicted apogee shall generate similar vibrations values.

There is also a strong need to consider impact of average lifespan of worker bee. It could interfere results, especially from 'PROtotype' rocket tests, where the same specimens were examined for 3 next days (Table 4).

\section{SUMMARY}

Research is still in developing stage, yet it had a few iterations, each one making corrections based on previous experiments. It is sure that further tests are needed in order to collect enough data for creating biocybernetic model of bee colony in conditions of rocket flight. Mechanical structure of payload is being redesigned in order to exclude the possibility of leaks and simplify assembling process, both of itself and with the rocket. Electronic subsystem will be additionally equipped with vibrometer, necessary to measure vibrations generated by different rockets used for the experiment, and oxygen sensor, to ensure better understanding of bees' respiration process.

Those preliminary studies shown that honeybees are able to survive rocket flight and initial acceleration related to rocket launch. However results from $23^{\text {rd }}$ of July are strongly disturbing and more tests should be performed to establish if the initial acceleration causes this significant drop of survivability value or it was only caused by workers average lifespan [15].

Surely there is more time needed between information about launch date and launch itself. Short time indisposed proper preparation to experiment and even made it impossible to conduct tests with queens on board.

During data analysis, specially statistical one, it is critical to consider average age of each worker bee. Moreover taken into consideration should be average lifespan on worker bees in different times in year [16].

Simultaneously research on rocket flight impact on honeybee queen reproduction traits is conducted. Author claims that proper reproduction is a key for later effective pollination and can be endangered because of potential impact of stress related to rocket launch on queen. In consequence such stress may contribute even to the queen's infertility. Those research along with described in this paper will be later the base for creating model of bee colony [17]. Such model will be examined in context of its usefulness for predicting the effects of giving the mother bee ( $A$. mellifera) stress associated with space flight.

Similar research should be done on bumblebees (Bombus), as more effective pollinator than $A$. mellifera [18]. This however requires General Directorate for Environmental Protection's approval, as most of Bombus species in Poland are protected.

\section{ACKNOWLEDGEMENT}

Research financed by AGH University of Science and Technology within the program 'Grant Rektorski 2018/2019’ granted to AGH Space Systems Science Club - grant number GR/104/2019.

The author is grateful to the article reviewers, whose comments were found very insightful and useful, to hers supervisors, Ryszard Tadeusiewicz and Michał Kolasa for help in research conception design and 
comments on the draft of the manuscript, to Bartosz Zieliński for designing and preparation of electronics subsystem of the experiment, to Michał Pyza for support and critical analysis of all mechanical parts of the payload, to Tomasz Tatara for help during data processing, to 'Pasieka Szeligów' apiary for providing the bees for experiment and substantive support and to Alan Fisher - beekeeper from New Mexico who provided honeybees during competition.

\section{REFERENCES}

[1] Mission to Mars, n.d., from https://www.spacex.com/mars, [access: July 2019]

[2] Why bees matter. The importance of bees and other pollinators for food and agriculture, 2018, Food and Agriculture Organization of the United Nations, Slovenia.

[3] Daily G. C., Ed., 1997, Nature’s Services: Societal Dependence On Natural Ecosystems, Island Press, Washington, D.C., Covelo, California, Chap. 8: Services Provided by Pollinators.

[4] Lucas, M., 2018, 'Megachile rotundata Proprioception and Flight Patterns in Microgravity', National Aeronautics and Space Administration (NASA), from https://www.nasa.gov/mission_pages/station/research/experiments/explorer/Investigation.html?\#i d=7838, [access: July 2019]

[5] Poskevich, D.M., 1984, 'A Comparison of Honeycomb Structures Built by Apis millifera (SE8217)', from https://lsda.jsc.nasa.gov/Experiment/exper/914, [access: May 2019]

[6] 'New Shepard Payloads - affordable acces to space', n.d., from https://www.blueorigin.com/newshepard/new-shepard-payloads/, [access: July 2019]

[7] Dell R. B., Holleran S., Ramakrishnan R., 2002, 'Sample size determination', ILAR journal, 43(4), pp. 207-213.

[8] Porogel Medium Spaceloft, n.d., from http://www.aerogels.pl/produkty/porogel/23-porogelmedium-spaceloft-2, [access: November 2018]

[9] URSA GLASSWOOL rolls, n.d., from https:/www.itb.pl/g/f/2604,ursa-glasswool-rolls, access: [November 2018]

[10] Dunham W.E., 1931, 'Hive temperatures for each hour of a day', The Ohio Journal of Science, 31(3), pp. 181-188.

[11] Abou-Shaara, H.F., Al-Ghamdi, A.A., Mohamed, 2012, 'Tolerance of two honey bee races to various temperature and relative humidity gradients', Environmental and Experimental Biology, 10, pp. $133-138$.

[12] Capinera J.L., 2008, Encyclopedia of Entomology, Springer, Dordrecht, Chap. Tracheal System and Respiratory Gas Exchange.

[13] Butler, C.G., 1954, 'The method and importance of the recognition by a colony of honeybees ( $A$. mellifera) of the presence of its queen', Transactions of the Royal Entomological Society of London, 105(2), pp. 11-29.

[14] Earth System Research Laboratory Global Monitoring Division, n.d., from https://www.esrl.noaa.gov/gmd/ccgg/trends/mlo.html, [access: August 2019]

[15] Rueppell O., Bachelier C., Fondrk M.K., Page Jr. R.E., 2007, 'Regulation of life history determines lifespan of worker honey bees (Apis mellifera L.)', Experimental Gerontology, 42(10), pp. 10201032.

[16] Amdam G.V., Omholt S.W., 2002, 'The regulatory anatomy of honeybee lifespan', Journal of Theoretical Biology, 216(2), pp. 209-228.

[17] Migacz A., Tadeusiewicz R., 1983, 'The computer model of the bee colony', Systems Science, 9(3), pp. 83-95.

[18] Thomson J.D., Goodell K., 2002, 'Pollen removal and deposition by honeybee and bumblebee visitors to apple and almond flowers', Journal of Applied Ecology, 38, pp. 1032-1044. 


\title{
OCENA WPEYWU LOTU RAKIETĄ NA KONDYCJE PSZCZÓŁ MIODNYCH (APIS MELLIFERA)
}

\begin{abstract}
Abstrakt
Artykuł dotyczy wpływu lotu rakietą na przeżywalność i ogólną kondycję osobników Apis mellifera (pszczoły miodnej). Autor twierdzi, że jest to kluczem dla wykorzystania ich w przyszłości na Marsie, jako najlepiej poznanego dotychczas gatunku zapylacza, i powinno zostać zbadane przed pierwszymi załogowymi misjami na Czerwoną Planetę. Ładunek rakietowy „BeeO!Logical” został stworzony w celu przeprowadzenia takich badań, pierwszych swojego typu na świecie. Zostały zaprezentowane założenia mu towarzyszące wraz z ogólnym opisem przeprowadzonych eksperymentów w dwóch rakietach sondujących. Przeanalizowano dane dotyczące przeżywalności, koncentracji dwutlenku węgla (poziomów respiracji), temperatury oraz wilgotności. Wykazano, że osobniki $A$. mellifera są w stanie przeżyć lot rakietą. Opisane zostały możliwości rozwoju projektu, włączając poszerzenie zakresu badań o testy na trzmielach (Bombus) oraz stworzenie modelu biocybernetycznego rodziny pszczelej.
\end{abstract}

Słowa kluczowe: pszczoły miodne, rakieta, ładunek, terraformacja Marsa. 